\title{
Pengaruh Pembelajaran Kooperatif Tipe Jigsaw Untuk Meningkatkan Pemahaman
}

\author{
${ }^{1}$ Eka Fitriani, ${ }^{2}$ Mahsup, ${ }^{3}$ Ibrahim \\ ${ }^{1}$ TK IT Abata Lombok, Indonesia \\ ${ }^{2}$ Pendidikan Matematika Universitas Muhammadiyah Mataram, Indonesia \\ ${ }^{3}$ Pendidikan Geografi Universitas Muhammadiyah Mataram, Indonesia \\ eka@gmail.com, supyeka@gmail.com, Ibrahimali.geo@gmail.com
}

\section{ARTICLE INFO}

Article History:

Received : 04-09-2018

Revised : 10-11-2018

Accepted : 16-11-2018

Online : 02-11-2018

Keywords:

Pengaruh; Tipe Jigsaw;

Pemahaman

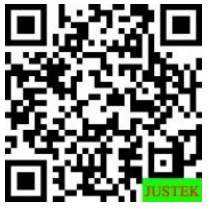

\begin{abstract}
Abstract: This research aims to determine the effect of cooperative learning of the jigsaw type in improving understanding of the material of elementary algebra students Semester II Study Program Mathematics education FKIP UM Mataram. This type of research is experimental research. The population in this study is all students of the second semester of Mathematics Education Study Program, while the sample of this research is five semester II students. The data collection techniques used are test instruments with a significant level of $5 \%$. Based on the results of the hypothesis test obtained that was done so that the alternative hypothesis (HA) was rejected and the zero hypothesis (Ho) was received. So that it can be concluded that there is no influence of the jigsaw method on the achievement of mathematical learning in the linear program of students Semester II Program of education Studies Mataram FKIP UM Mataram Tuliskan abstrak dalam bahasa Inggris
\end{abstract}

\begin{abstract}
Abstrak: Penelitian ini bertujuan untuk mengetahui Pengaruh pembelajaran kooperatif tipe jigsaw dalam meningkatkan pemahaman materi Aljabar Elementer mahasiswa semester II Program Studi Pendidikan Matematika FKIP UM Mataram. Jenis penelitian ini adalah penelitian eksperimen. Populasi dalam penelitian ini adalah seluruh mahasiswa semester II program Studi Pendidikan Matematika, sedangkan sampel penelitian ini adalah 5 orang mahasiswa semester II. Tehnik pengumpulan data yang digunakan adalah instrumen test dengan taraf signifikan 5\%. Berdasarkan hasil pengujian hipotesis didapatkan yang telah dilakukan sehingga hipotesis alternatif $(\mathrm{Ha})$ ditolak dan hipotesis nol (Ho) diterima. Sehingga dapat disimpulkan bahwa tidak ada pengaruh metode jigsaw terhadap prestasi belajar matematika pada materi program linear Mahasiswa Semester II Program Studi Pendidikan Mataram FKIP UM Mataram.
\end{abstract}

doi) 8 Crossref

https://doi.org/10.31764/justek.vXiY.3541

This is an open access article under the CC-BY-SA license

\section{A. LATAR BELAKANG}

Menghadapi era globalisasi yang diiringi dengan perkembangan ilmu pengetahuan dan teknologi (IPTEK) yang sangat pesat, maka peningkatan kualitas sumber daya manusia mempunyai posisi yang strategis bagi kelanjutan dan pembangunan suatu bangsa (Setyowati, Kristin, and Anugraheni 2018)(Mahsup and Anwar 2020). Salah satu wadah bagi upaya peningkatan kualitas sumber daya manusia adalah dalam bidang 
pendidikan(Mahsup and Anwar 2020). Ada bebrapa indikator dalam peningkatan mutu pendidikan antara lain melalui peningkatan kinerja guru dan peningkatan mutu pembelajaran (Mandailina and Mahsup 2018)(Aribawati, Kristin, and ... 2018).

Pendidikan merupakan upaya manusia untuk memperluas pengetahuan dalam rangka membentuk nilai, sikap, dan perilaku (Rahmatin et al. 2019). Selain itu pendidikan juga merupakan suatu cara pembentukan manusia untuk belajar menggunakan rasionya seefektif dan seefesien mungkin untuk menjawab berbagai masalah yang timbul dalam usaha menciptakan masa depan yang lebih baik, atau mengadakan perubahan-perubahan yang disebut dengan kemajuan (Kabunggul et al. 2020)(Adriyanto, Dewi Pramita, Abdillah, Syaharuddin, Mahsup 2019). Hal ini akan dicapai apabila dalam proses belajar mengajar diselenggarakan secara profesional serta kurikulum yang disajikan telah sesuai dengan perkembangan dan kebutuhan masyarakat (Leonardo and Wijaya 2019)(Mahsup 2011)(Mahsup and Anwar 2020).

Selama ini banyak keluhan tentang mahasiswa yang kurang mandiri, kurang menghargai pendapat orang lain, mahasiswa yang kurang mau bekerja sama atau membantu teman (Murtiah 2018)(Mukminah, Eka Fitriani, Mahsup 2019). Pembelajaran yang efektif untuk memperoleh keberhasilan semua pihak, baik keberhasilan dosen dan terutama keberhasilan mahasiswa secara terus menerus diupayakan, dicari, dicoba dan diteliti (Junaedi 2019)(Nurfiati, Vera Mandailina, Mahsup, Syaharuddin 2020). Selain itu, tuntutan semakin kompleksnya persoalan ditengah kehidupan masyarakat, tuntutan pasar yang makin kompetitif, teknologi semakin berkembang, maka tuntutan strategi pembelajaran yang efektif perlu dilakukan (Salati 2015)(Mahsup and Anwar 2020)(Mahsup and Anwar 2017).

Permasalahan yang kerap terjadi pada proses pembelajaran secara umum adalah model pembelajaran yang digunakan masih bersifat konvensional yang berdampak pada kurangnya hasil belajar mahasiswa karena keseringan mahasiswa mengalami kesulitan yang tidak terpecahkan dalam memahami setiap materi ajar (Arta Diantoro, Mahsup, and Pramita 2019)(Puspita, Slameto, and ... 2018)(Mahsup, Islahudin, and Anwar 2018).

Para ahli pendidikan matematika mencoba mengembangkan model pemecahan masalah umum untuk menjelaskan proses yang terjadi pada pemecahan masalah (Syaharuddin, Pramita, and Sirajuddin 2019)(Mahsup and Abdillah 2019). Tujuan umum pendidikan matematika, mempelajari matematika tidak hanya menghitung semata, tetapi mahasiswa diharapkan mampu bernalar, berpikir kritis serta logis, dapat memecahkan masalah matematis, masalah dalam bidang ilmu lain serta masalah dalam kehidupan sehari-hari (Lingga and Sari 2013)(Murtiah 2018)(Mahsup et al. 2020).

Berdasarkan hasil pengamatan peneliti pada mahasiswa semester II bahwa kemampuan mahasiswa dalam berpikir kritis dan logis dalam memahami materi Determinan masih kurang dan mahasiswa juga masih kesulitan dalam menyelesaikan permasalahan determinan jika dikaitkan dengan permasalahan dalam kehidupan seharihari. Mahasiswa juga masih kesulitan dalam menterjemahkan soal-soal yang berbentuk soal cerita ke dalam simbol matematika akibatnya mahasiswa tidak mampu menyelesaikan soal tersebut.

Kurangnya pemahaman mahasiswa dalam memahami materi determinan berakibat juga pada nilai quiz mahasaiswa, diamana nilai mahasiswa berada pada kategori rendah dengan memperoleh rata-rata nilai 65. Selain itu mahasiswa juga masih pasif dalam proses diskusi dikelas, sehingga kemampuan dalam memahami materi yang diajarkan belum bisa diterima dan dipahami dengan baik. Untuk itu dalam proses belajar mengajar dosen sangat diperlukan untuk mengatasi kesulitan menyelesaikan soal-soal determinan. Oleh karena dosen perlu mengetahui kesulitan mahasiswa dalam 
menyelesaikan soal-soal matematika dan dapat menggali penyebab mahasiswa tidak aktif dalam melakukan proses diskusi. Dengan demikian diharapkan dosen dapat menentukan usaha yang tepat untuk mengatasi masalah tersebut untuk perbaikan dalam pembelajaran matematika.

Dengan demikian dosen dapat menggunakan metode active learning yang membuat pembelajaran matematika menjadi menyenangkan dan tidak hanya berpusat pada dosen saja melainkan berpusat juga pada mahasiswa, sehingga dapat menumbuhkan dan mengembangkan kepercayaan diri mahasiswa. Metode active learning diantaranya metode Jigsaw (Andriani, Munawaroh, and Nursuprianah 2015). Pembelajaran kooperatif tipe jigsaw ini dapat meningkatkan motivasi mahasiswa untuk belajar bersama dengan membentuk suatu kelompok dan para anggota bertanggung jawab atas topik yang dibicarakan (Muhammad 2018). Adanya tanggung jawab para mahasiswa dalam melakukan dan mempelajari topik-topik tertentu diharapkan dapat menjadi bagian yang tidak terpisahkan dalam belajar mahasiswa untuk mencapai tujuan dan prestasi belajarnya yang lebih baik (Sulthani 2013)

Kelebihan pembelajaran kooperatif tipe jigsaw adalah sebagai berikut : (1) Mempermudah pekerjaan dosen dalam mengajar, karena sudah ada kelompok ahli yang bertugas menjelaskan materi kepada rekan-rekannya. (2) Mengembangkan kemampuan mahasiswa mengungkapkan ide atau gagasan dalam memecahkan masalah tanpa takut membuat salah. (3) Dapat meningkatkan kemampuan sosial: mengembangkan rasa harga diri dan hubungan interpersonal yang positif. (4) Mahasiswa lebih aktif dalam berbicara dan berpendapat karena mahasiswa diberikan kesempatan untuk berdiskusi dan menjelaskan materi pada masing-masing kelompok. (5) Mahasiswa lebih memahami materi yang diberikan karena dipelajari lebih dalam dan sederhana dengan anggota kelompoknya. (6) Mahasiswa lebih menguasai materi karena mampu mengajarkan materi tersebut kepada teman kelompok belajarnya. (7) Mahasiswa diajarkan bagaimana bekerja sama dalam kelompok. (8) Materi yang diberikan kepada mahasiswa dapat merata. (9) Dalam proses belajar mengajar mahasiswa saling ketergantungan positif (Muhammad 2018).

Tujuan dalam penelitian ini adalah untuk mengetahui Pengaruh pembelajaran kooperatif tipe jigsaw dalam meningkatkan hasil belajar pada materi determinan mahasiswa semester II Program Studi Pendidikan Matematika FKIP UM Mataram.

\section{B. METODE PENELITIAN}

Jenis Penelitian ini menggunakan metode eksperimen jenis quasi experiment. Desain yang digunakan dalam penelitian ini adalah desain Nonequivalent (pretest-posttest) Control Group Design. Adapun rancangan penelitian yang digunakan adalah desain kelompok kontrol dan eksperimen dengan post-test. Untuk lebih jelasnya desain penelitian digambarkan pada tabel 1 berikut:

\begin{tabular}{lcc}
\multicolumn{2}{c}{ Tabel 1. Rancangan Penelitian } \\
\hline Kelompok & Perlakuan & $\begin{array}{c}\text { Post- } \\
\text { test }\end{array}$ \\
\hline Eksperimen & $\mathrm{X}_{1}$ & $\mathrm{O}_{1}$ \\
Kontrol & $\mathrm{X}_{2}$ & $\mathrm{O}_{2}$
\end{tabular}

Dalam penelitian ini yang menjadi kelompok eksperimen dan kelompok kontrol adalah mahasiswa semester II sebanyak 5 orang. Teknik pengumpulan data yang digunakan dalam penelitian ini adalah (1) tes dengan data hasil belajar, (2) observasi dengan data aktivitas pembelajaran mahasiswa dan dosen. Tes hasil belajar digunakan dalam penelitian ini untuk mengukur hasil belajar mahasiswa dengan memberikan pre- 
tes dan post-tes. Sedangkan observasi digunakan untuk mengukur aktivitas yang dilakukan oleh mahasiswa dan dosen selama proses pembelajaran berlangsung.

Analisis data dalam penelitian ini adalah skor hasil post-test mahasiswa kelompok eksperimen dan kelompok kontrol. Setelah data yang diperoleh dilakukan analisis data untuk menguji dengan skor rata-rata mahasiswa kelompok eksperimen dan kontrol. Untuk mengetahui perbedaan hasil belajar terhadap materi determinan yang diajarkan menggunakan pembelajaran kooperatif tipe jigsaw pada kelompok eksperimen dan pendekatan metode biasa pada kelompok kontrol pada semsester II, maka dilakukan dengan langkah-langkah pengolahan data yakni: pemberian skor, uji normalitas menggunakan Chi-kuadrat, uji homogenitas menggunakan uji F, uji hipotesis (uji-t) pihak kanan dengan menggunakan Independent Sample T-test dengan perhitungan secara manual. Rumus uji hipotesis (uji-t) Independent Sample T-test adalah :

$t=\frac{\bar{x}_{1}-\bar{x}_{2}}{\sqrt{\frac{s_{1}^{2}}{n_{1}}+\frac{s_{2}^{2}}{n_{2}}\left(\frac{s_{1}}{\sqrt{n_{1}}}+\frac{s_{2}}{\sqrt{n_{2}}}\right)}}$ (Arikunto 2008)

\section{HASIL DAN PEMBAHASAN}

\section{Deskripsi Data Hasil Belajar}

Data hasil belajar diperoleh setelah diberikannya perlakuan pada kelompok eksprimen dan kelompok kontrol. Data yang diperoleh untuk mengetahui hasil belajar mahasiswa yaitu melalui pemberian post-tes. Dari hasil pengumpulan data selama penelitian didapatkan hasil sebagaimana tertera dalam tabel 2 berikut.

Tabel 2. Deskripsi Data Hasil Penelitian

\begin{tabular}{clccc}
\hline No & Kelompok & $\begin{array}{c}\text { Nilai } \\
\text { Maks }\end{array}$ & $\begin{array}{c}\text { Nilai } \\
\text { Min }\end{array}$ & $\begin{array}{c}\text { Rata- } \\
\text { rata }\end{array}$ \\
\hline 1 & Eksperimen & 90 & 62 & 76 \\
2 & Kontrol & 75 & 60 & 67.5
\end{tabular}

\section{Hasil Pengujian Hipotesis}

Tabel 3. Uji Normalitas Data Pre-Tes

\begin{tabular}{ccccc}
\hline Kelas & $\mathrm{N}$ & $X^{2}{ }_{\text {hitung }}$ & $X^{2}{ }_{\text {tabel }}$ & Kesimpulan \\
\hline Eksperimen & 2 & $-33,53$ & 11,07 & Normal \\
Kontrol & 2 & $-12,42$ & 11,07 & Normal
\end{tabular}

Tabel 3 menunjukkan bahwa hasil perhitungan uji normalitas data pre-test kelas eksperimen dan kelas kontrol dengan membandingkan harga chi kuadrat hitung dengan chi kuadrat tabel. Dari hasil analisis diperoleh $X_{\text {hitung }}^{2}=-33,53$ dan $X_{\text {tabel }}^{2}=11,07$. Karena $X_{\text {hitung }}^{2}<X_{\text {tabel }}^{2}$ berarti data pada kelas eksperimen yang diperoleh berdistribusi normal. Sedangkan hasil uji normalitas pada kelas kontrol diperoleh $X_{\text {hitung }}^{2}=-12,42$ dan $X_{\text {tabel }}^{2}=11,07$. Karena $X_{\text {hitung }}^{2}<X_{\text {tabel }}^{2}$ berarti data yang diperoleh berdistribusi normal. Jadi nilai awal pada kelompok kontrol dan eksperimen berdistribusi normal. Hasil uji normalitas data post-tes disajikan dalam tabel 4 berikut.

Tabel 4. Uji Normalitas Data Post-tes

\begin{tabular}{ccccc}
\hline Kelas & $\mathrm{N}$ & $X^{2}{ }_{\text {hitung }}$ & $X^{2}{ }_{\text {tabel }}$ & Kesimpulan \\
\hline Eksperimen & 2 & $-21,23$ & 11,07 & Normal \\
Kontrol & 2 & $-20,26$ & 11,07 & Normal
\end{tabular}


Tabel 4 menunjukkan bahwa hasil perhitungan uji normalitas data pos-test kelas eksperimen dan kelas kontrol dengan membandingkan harga chi kuadrat hitung dengan chi kuadrat tabel. Dari hasil analisis diperoleh $X_{\text {hitung }}^{2}=-21,23$ dan $X_{\text {tabel }}^{2}=11,07$. Karena $X_{\text {hitung }}^{2}<X_{\text {tabel }}^{2}$ berarti data pada kelas eksperimen yang diperoleh berdistribusi normal. Sedangkan hasil uji normalitas pada kelas kontrol diperoleh $X_{\text {hitung }}^{2}=-20,26$ dan $X_{\text {tabel }}^{2}=$ 11,07. Karena $X_{\text {hitung }}^{2}<X_{\text {蓦abel }}^{2}$ berarti data yang diperoleh berdistribusi normal. Jadi nilai akhir pada kelompok eksperimen dan kontrol berdistribusi normal. Sedangkan hasil Uji Homogenitas post-tes dalam penelitian ini disajikan dalam tabel 5 berikut.

Tabel 5. Uji Homogenitas Data Post-tes

\begin{tabular}{lcccc}
\hline \multicolumn{1}{c}{ Kelas } & N & F_hitung & F_tabel & Keterangan \\
\hline Eksperimen & 2 & 1,535 & 2,12 & Homogen \\
Kontrol & 2 & & &
\end{tabular}

Tabel 5 menunjukan bahwa hasil perhitungan pada data post-tes diperoleh $F_{\text {hitung }}=$ 1,535 dan Ftabel = 2,12 pada taraf signifikan 5\% dengan d $\mathrm{k}$ pembilang $(n-1)=21-1=20$ dan $d k$ penyebut $(n-1)=21-1=20$, tampak bahwa $F_{\text {hitung }}<\mathrm{F}_{\text {tabel }}$ sehingga menunjukkan varians homogen. Untuk menguji kreteria " $t$ " maka diajukan hipotesis yaitu "Ha diterima jika $t_{\text {hitung }}>t$ tabel" dengan $d k=N 1+N 2-2$ pada taraf signifikan 5\% dengan uji satu pihak. Berdasarkan pengujian yang dilakukan, maka didapatkan $t_{\text {hitung }}=2,473$ sedangkan $t_{\text {tabel }}=$ 2,02 dapat disimpulkan bahwa $t$ hitung $=2,473>t$ tabel $=2,02$ ini berarti bahwa hipotesis alternatif $(\mathrm{Ha})$ diterima.

\section{Hasil Observasi}

Proses observasi dilaksanakan oleh dosen bidang studi pendidikan matematika selama proses belajar mengajar dengan mengisi lembar observasi yang telah disiapkan. Berdasarkan hasil observasi mahasiswa pada pembelajaran I terdapat beberapa hambatan dan kekurangan yaitu (a) kurangnya semangat mahasiswa untuk belajar, (b) mahasiswa terpengaruh terhadap gangguan dari luar selama pembelajaran berlangsung dan (c) tidak semua mahasiswa aktif dalam proses pembelajaran. Adapun hasil Observasi aktivitas mahasiswa dalam pembelajaran disajikan dalam tabel 6 berikut :

Tabel 6. Hasil Observasi Siswa Pada Pembelajaran I

\begin{tabular}{lc}
\hline \multicolumn{1}{c}{ Item } & Hasil Yang Diperoleh \\
\hline Jumlah siswa seluruhnya & 5 \\
Banyak aspek yang diamati & 5 \\
Skor total & 20 \\
Skor yang diperoleh & 10 \\
Pesentase & $54 \%$ \\
Kategori & Cukup
\end{tabular}

Pada pembelajaran I skor yang diperoleh 10 dengan persentase aktivitas mahasiswa selama pembelajaran sebesar 54\%. Selanjutnya hasil observasi dosen pada pembelajaran I secara ringkas dapat dilihat pada tabel 7 berikut.

Tabel 7. Hasil Observasi Dosen Pada Pembelajaran I

\begin{tabular}{lc}
\hline \multicolumn{1}{c}{ Item } & Hasil yang diperoleh \\
\hline Jumlah skor aktivitas dosen & 28 \\
Jumlah skor seluruhnya & 48 \\
Banyak aspek yang diamati & 12 \\
Persentase & $58,33 \%$ \\
Kategori & Baik
\end{tabular}

Berdasarkan hasil observasi pengelolaan pembelajaran oleh dosen pada kelas eksperimen selama pembelajaran memperoleh skor 28 dengan persentase kemampuan 
dosen dalam mengelola pembelajaran sebesar 58,33 \%. Selanjutnya hasil observasi mahasiswa pada pembelajaran II secara ringkas dapat dilihat pada tabel 8 berikut.

Tabel 8. Hasil Observasi Mahasiswa Pada Pembelajaran II

\begin{tabular}{lc}
\hline \multicolumn{1}{c}{ Item } & Hasil Yang Diperoleh \\
\hline Jumlah mahasiswa seluruhnya & 5 \\
Banyak aspek yang diamati & 5 \\
Skor total & 20 \\
Skor yang diperoleh & 11 \\
Pesentase & $55 \%$ \\
Kategori & Baik
\end{tabular}

Pada pembelajaran II skor yang diperoleh 11 dengan persentase aktivitas mahasiswa selama pembelajaran sebesar 55\%. Selanjutnya hasil observasi dosen pada pembelajaran II secara ringkas dapat dilihat pada tabel 9.

Tabel 9. Hasil Observasi Dosen Pada Pembelajaran II

\begin{tabular}{lc}
\hline \multicolumn{1}{c}{ Item } & Hasil yang diperoleh \\
\hline Jumlah skor aktivitas dosen & 27 \\
Jumlah skor seluruhnya & 44 \\
Banyak aspek yang diamati & 11 \\
Persentase & $61,36 \%$ \\
Kategori & Baik
\end{tabular}

Berdasarkan hasil observasi pengelolaan dosen pada pembelajaran II kelas eksperimen selama pembelajaran memperoleh skor 27 dengan persentase kemampuan dosen mengelola pembelajaran $61,36 \%$. Sedangkan hasil observasi mahasiswa pada pembelajaran III dengan jumlah mahasiswa seluruhnya sebanyak 21 , banyak aspek yang diamati 5, skor total 20 dan Skor yang diperoleh 13 dengan persentase $65 \%$ pada Kategori baik. Pada pembelajaran III skor yang diperoleh 13 dengan persentase aktivitas mahasiswa selama pembelajaran sebesar 65. Selanjutnya hasil observasi dosen pada pembelajaran III dimana jumlah skor aktivitas dosen dengan hasil 29 dengan jumlah skor seluruhnya 44, banyak aspek yang diamati adalah 11 dengan presentase 65,90\% berada pada kategori baik. Berdasarkan hasil observasi pengelolaan dosen pada pembelajaran III kelas eksperimen selama pembelajaran memperoleh skor 29 dengan persentase kemampuan dosen mengelola pembelajaran 65,90\%.

Penggunaan model pembelajaran Jigsaw ini telah membuat mahasiswa melakukan kegiatan dalam belajar dengan baik yang tentunya berpengaruh baik pula terhadap pencapaian hasil belajar mahasiswa itu sendiri. Selain itu, dengan penggunaan model pembelajaran Jigsaw proses pembelajaran menjadi menyenangkan. Pembelajaran kooperatif tipe jigsaw dapat membantu mahasiswa untuk terlibat aktif dalam proses belajar mengajar. Akan tetapi salah satu poin yang menarik untuk dijadikan catatan adalah bahwa metode atau model pembelajaran yang menekankan agar mahasiswa terlibat aktif dalam proses belajar tidak selalu mudah. Terdapat beberapa kendala selama proses pembelajaran berlangsung yaitu (1) mahasiswa masih ada yang tidak serius ikut berdiskusi (2) mahasiswa masih ribut pada saat kegiatan presentasi sehingga tidak memperhatikan temannya yang sedang menyampaikan hasil diskusi kelompoknya (3) ada beberapa mahasiswa pasif dalam diskusi kelompok. Dalam proses belajar mengajar ada mahasiswa yang mengalami kesulitan belajar sehingga tidak mampu mencapai ketuntasan belajar.

\section{SIMPULAN DAN SARAN}

Berdasarkan hasil penelitian dapat disimpulkan bahwa nilai thitung $=2,473$ sedangkan 
$t_{\text {tabel }}=2,02$ sehingga dapat disimpulkan bahwa $t$ hitung $=2,473>t$ tabel $=2,02$ ini berarti bahwa hipotesis alternatif ( $\mathrm{Ha}$ ) diterima. Saran bagi mahasiswa diharapkan membiasakan diri untuk menanyakan materi yang dianggap sulit dan belum dimengerti serta tanpa ragu menanggapi pertanyaan-pertanyaan dari dosen maupun temantemannya. Sedangkan saran bagi peneliti untuk kedepannya diharapkan dapat lebih profesional dalam menerapkan model pembelajaran jigsaw dan mencoba menerapkannya pada materi pokok yang lain dengan cakupan yang lebih luas.

\section{UCAPAN TERIMA KASIH}

Judul untuk ucapan terima kasih kepada LPPM Universitas Muhammadiyah Mataram yang telah memberikan dana dan dukungan terhadap pelaksanaan penelitian ini.

\section{REFERENSI}

Adriyanto, Dewi Pramita, Abdillah, Syaharuddin, Mahsup, Eka Fitriani. 2019. "Peningkatan Kompetensi Strategis Siswa Melalui Model Pembelajaran Conceptual Understanding Procedures." Justek: Jurnal Sains dan Teknologi 2(1): 01-10. http://journal.ummat.ac.id/index.php/justek/article/view/3535/pdf.

Andriani, Ineu, Mumun Munawaroh, and Indah Nursuprianah. 2015. "Perbandingan Kepercayaan Diri Siswa Dalam Belajar Matematika Antara Yang Menggunakan Metode Jigsaw Dengan Metode Inkuiri Terbimbing Di Kelas VII SMP Satu Atap Negeri Talun Kabupaten Cirebon." Kata Kunci: Kepercayaan Diri, Metode Jigsaw Metode Inkuiri Terbimbing EduMa 4(2): 32-45.

Aribawati, D, F Kristin, and ... 2018. "Penerapan Model Pembelajaran Inkuiri Terbimbing Untuk Meningkatkan Kreativitas Dan Hasil Belajar IPA Siswa Kelas 3 SD." Justek/ Jurnal Sains \& ....

Arikunto, Suharsimi. 2008. "Evaluasi Program Pendidikan." PT bumi aksara: 227.

Arta Diantoro, Syaiful Barsa, Mahsup Mahsup, and Dewi Pramita. 2019. "Penerapan Model Pembelajaran Kooperatif Tipe Two Stay Two Stray (TSTS) Dalam Meningkatkan Hasil Belajar Bentuk Aljabar Siswa Kelas VII SMP." Paedagoria / FKIP UMMat 10(1): 01.

Junaedi, Ifan. 2019. "Proses Pembelajaran Yang Efektif." Journal of Information System, Applied, Management, Accounting and Research 3(2): 19-25.

Kabunggul, Yosua et al. 2020. "Meningkatkan Motivasi Dan Hasil Belajar Siswa Melalui Penerapan Model Pembelajaran Team Game Tournament Berbantuan Media ...." Jurnal Pendidikan Karakter 3(2): 3-6.

Leonardo, Leonardo, and Michelle Aprilia Wijaya. 2019. "Pengaruh Desain Pencahayaan Kelas Terhadap Proses Belajar Mengajar Di Universitas Matana.” Media Arsitektur dan Kota : Jurnal Ilmiah Penelitian 2(2): 61-71.

Lingga, Alif, and Winda Sari. 2013. "Pengaruh Kemampuan Berpikir Aljabar Terhadap Kemampuan Pemecahan Masalah Matematika (Studi Kasus Di Kelas VIII SMP Negeri 1 Kaliwedi Kabupaten Cirebon)." Eduma 2(2).

Mahsup, and Abdillah Abdillah. 2019. "Penerapan Pembelajaran Metode Diskusi Untuk Meningkatkan Hasil Belajar Matematika Mahasiswa Pada Materi Determinan." Jurnal Ulul Albab 23(1): 33.

Mahsup, and Y. S. Anwar. 2020. "Development of Structured Modules to Improve the Mathematical Understanding of the Circle Concept in Class VIII Mataram 17 Junior High School." In Journal of Physics: Conference Series,.

Mahsup, Mahsup. 2011. "Penerapan Stategi Inquiri Untuk Meningkatkan Hasil Belajar Tentang Sistem Persamaan Linear Dua Variabel." Beta 4(2): 120-32. 
file://C:/Users/Mahsup/Downloads/document (1).pdf.

—_- 2020. "Peningkatan Hasil Belajar Mahasiswa Melalui Model Pembelajaran Tutor Sebaya." Jurnal Kependidikan: Jurnal Hasil Penelitian dan Kajian Kepustakaan di Bidang Pendidikan, Pengajaran dan Pembelajaran.

Mahsup, Mahsup, and Yunita Septiana Anwar. 2017. "Sosialisasi Media Pita Bilangan Matematika Siswa Sekolah Dasar Desa Gelangsar Lombok Barat." JMM Uurnal Masyarakat Mandiri) 1(1): 25.

Mahsup, Mahsup, Islahudin Islahudin, and Yunita Septriana Anwar. 2018. "Pelatihan Penggunaan Media Pembelajaran Untuk Meningkatkan Pemahaman Dalam Menentukan Volume Bangun Ruang Bagi Siswa Sekolah Dasar." Selaparang Jurnal Pengabdian Masyarakat Berkemajuan 2(1): 27.

Mandailina, Vera, and Mahsup. 2018. "Efektivitas Pembelajaran Matematika Dengan Metode Thinking Aloud Pair Problem Solving (TAPPS) Terhadap Hasil Belajar Siswa Pokok Bahasan Kubus Dan Balok Kelas VIII SMP/MTs." Jurnal Teori dan Aplikasi Matematika (JTAM) 2(2): 144-47.

Muhammad, Zulfikar. 2018. "Pengaruh Metode Pembelajaran Kooperatif Tipe Jigsaw Terhadap Motivasi Dan Hasil Belajar Mahasiswa." Jurnal Pembelajaran Matematika 9: 65-71.

Mukminah, Eka Fitriani, Mahsup, Syaharuddin. 2019. "Efektifitas Model Pembelajaran Kooperatif Tipe Teams Games Tournament Untuk Meningkatkan Hasil Belajar." Justek: Jurnal Sains dan Teknologi 2(2): 1-5. http://journal.ummat.ac.id/index.php/justek/article/view/3533.

Murtiah, B. 2018. "Penerapan Pendekatan Kontekstual Menggunakan Media Gambar Binatang Untuk Meningkatkan Keterampilan Mendeskripsi Secara ...." Justek/ Jurnal Sains \& Teknologi.

Nurfiati, Vera Mandailina, Mahsup, Syaharuddin, Abdillah. 2020. "Effect of Make A Match Learning Model on Student Learning Outcomes on Statistical Materials." Justek: Jurnal Sains dan Teknologi 3(1): 1-8. http://journal.ummat.ac.id/index.php/justek/article/view/3509.

Puspita, M, S Slameto, and ... 2018. "Peningkatkan Hasil Belajar Matematika Siswa Kelas 4 Sd Melalui Model Pembelajaran Problem Based Learning." Justek/ Jurnal Sains \& ....

Rahmatin, Nutia, Dewi Pramita, Sirajuddin Sirajuddin, and Mahsup Mahsup. 2019. "Pengembangan Modul Pembelajaran Bangun Ruang Dengan Metode Creative Problem Solving (CPS) Pada Siswa Kelas VIII SMP." JTAM / Jurnal Teori dan Aplikasi Matematika 3(1): 27.

Salati, Suriansyah. 2015. "Strategi Mengaktifkan Siswa Belajar Aktif (Active Learning) Dalam Pelaksanaan Proses Pembelajaran." Jurnal Ta'lim Muta'allim 1(2): 5.

Setyowati, Endah, Firosalia Kristin, and Indri Anugraheni. 2018. "Penggunaan Model Pembelajaran Discovery Learning Untuk Meningkatkan Kreativitas Dan Hasil Belajar Siswa Kelas 5 SD Negeri Mangunsari 07." Justek/ Jurnal Sains \& Teknologi 1(1): 76-81.

Sulthani, N.A Zavy. 2013. "Kemampuan Komunikasi Matematis Siswa Kelas Unggulan Dan Siswa Kelas Reguler Kelas X Sma Panjura Malang Pada Materi Logika Matematika." Jurnal Pembelajaran Matematika 3(2): 1-8.

Syaharuddin, Syaharuddin, Dewi Pramita, and Sirajuddin Sirajuddin. 2019. "Pengenalan Operasi Tambah Kurang Melalui Permainan Congklak Bagi Siswa Sekolah Dasar." JMM (Jurnal Masyarakat Mandiri) 3(1): 01. 